\title{
A COMPARISON OF PHYSICAL EDUCATION (PE) DEVELOPMENT IN THE CZECH REPUBLIC, GERMANY, AND THE USA - A HISTORICAL PERSPECTIVE
}

\author{
Petr Vlček
}

Faculty of Education, Masaryk Univerzity, Brno, Czech Republic

Submitted in August, 2009

BACKGROUND: After the year 1989, political, structural and economic reforms caused significant changes in education in the Czech Republic, also affecting physical education (PE). Within the context of unification and globalization there are similar changes in progress in other countries.

OBJECTIVE: The complex situation, fast changes and various pedagogical traditions complicate the creation of a systematic view of the current PE reforms. The objective of this paper is to describe the most important events in the history of PE in the Czech Republic, Germany and the USA and to explain their effect on the PE curriculum changes in the selected countries. The purpose of this historical analysis is to present some fundamental information about the development of PE in selected countries which will make possible further comparisons of the current reforms of physical education.

METHODS: Our methodology is based on historical comparison outlining and comparing the history of the PE concepts in selected countries.

RESULTS: Our results and findings show the differences in the history of PE in the Czech Republic, Germany and the USA and the crosscultural influence of the countries on the development of PE concepts. Especially the Turners from Germany influenced the beginnings of Czech and American PE in the $19^{\text {th }}$ century. Other gymnastic systems entered the USA later but the philosophy of pragmatism and the influence of the modern Olympic movement brought significant changes into the American PE concept at the beginning of the $20^{\text {th }}$ century. As a consequence, the gymnastic systems have been replaced with the "sport recreational" concept. In the $20^{\text {th }}$ century the emphasis on physical education changed repeatedly when conflicts between countries occurred. For example the German, Czech and American PE emphasis shifted from games and sport to physical conditioning after WWI and WWII and also after the Korean and Vietnam War in the USA. Further differences in PE concepts were caused by diverse political ideologies in the second half of the $20^{\text {th }}$ century. Physical education in the former Czechoslovakia was influenced by the Soviet physical culture philosophy. Popularity of sport in the 1960's and the 1970's affected the PE curricula in Western Germany, but later, in the 1980's, sport decreased in importance. After the end of the "Cold War", PE focussed on "life long activities," and the influence of American culture was visible in the PE development in European countries. Recently, an active life style has been supported and the issue of health has become an important part of the PE curricula.

CONCLUSIONS: The results of this analysis confirm different approaches to physical education concepts among these countries in terminology, roles, and goals during different time periods. Our findings also show that the educational reforms in Germany and the USA were started 10 and 20 years earlier than in the Czech Republic. Therefore, it is important to carry out further comparisons of current educational reforms that might help to reform Czech physical education.

Keywords: History, concept of physical education, the Czech Republic, Germany, the USA.

\section{INTRODUCTION}

The concepts of physical education in different countries are diverse. Even their terminology is not the same. In the USA and in the Czech Republic as well, the term physical education is used, but in Germany it is called "Sportunterricht," which means something like "the teaching of sport" or "lessons in sport." Physical education was re-termed in the GDR in 1965, Western Germany followed after 1970 (Balz \& Neumann, 2005).
Taking these differences into account, we can agree with Naul (2003) who admits that it is not wholly surprising that different and various concepts of the subject exist in terms of the curriculum.

Throughout history the status of physical education has developed. In our considerations we also agree with Brettschneider (1997) and many other authors (Cazers \& Miller, 2000; Kössel, Štumbauer, \& Waic, 2004; Naul, 2003; Siedentop, 2006) that from the late $17^{\text {th }}$ century to the mid $18^{\text {th }}$ century three systems (the German, 
Swedish, and English) laid the foundations of sport and physical education in many countries across the world. Naul (2003) recognises four concepts of PE (sport, movement, physical and health) which developed in the $19^{\text {th }}$ century and are more or less predominant in various countries today.

In contrast to Naul (2003), who paid attention mostly to the western European countries, we would like to add some more components from the Czech point of view. Dimilarly to Naul (2003), not many Czech authors have paid attention to the American history of PE. We would also like to enrich Naul's thoughts about the history of PE with some information from the USA.

\section{METHODS}

This methodology is based on comparative physical education and sport which is a discipline first described by Bennett (1970). In the recent years this scientific field is gaining in popularity ${ }^{1}$ which is visible not only due to the number of articles dedicated to the methodology of comparative physical education and sport (Hardman, 2000; Kaulitz, 2001; Kudlorz, 1989; Pühse \& Gerber, 2005) but also due to the growing number of comparative studies in different areas of physical education and sport $^{2}$. The International Society for Comparative Physical Education and Sport (ISCPES) publishes its magazine called the Journal of Comparative Physical Education (recently renamed International Sport Studies). It contains eight main topics into which the articles are divided (Editorial, 2004):

- Instructional theory of sport;

- Health foundations;

- Curriculum theory of sport;

- Historical-philosophical foundations;

- Physical education teacher and coach education;

- Psychological-sociological foundations;

- Comparative sport pedagogy;

- Nature and function of sport pedagogy.

Also Kaulitz (2001) divides the areas of comparative research in physical education and sport into different areas. As a basis for comparative research, she stresses the importance of historical comparison from an international perspective. Kaulitz reminds us of some publications dedicated to this field of comparative research such as "The German contribution to American physical education: A historical perspective" (Cazers $\&$ Miller, 2000). In our article we were inspired by Cazers and Miller who described the German contribution to American physical education mainly in the $19^{\text {th }}$ cen-

\footnotetext{
${ }_{1}$ Especially with English and German writing authors.

2 Vlček (2009b) presents a list of the most important publications dedicated to the comparative research in physical education written by Czech, English and German writing authors.
}

tury. In contrast to Cazers and Miller we would like to summarize the further development in the $20^{\text {th }}$ century and the contribution of American culture to the European development of PE.

Hagg (1989) names two dimensions for comparative research:

- horizontal - comparison of different social settings at a given time,

- vertical - comparison of different time periods regarded to fixed questions.

As Fig. 1 shows, we describe the development of physical education concepts in three different countries (the horizontal approach) and in different time periods (the vertical approach). As the method of our research we have chosen the qualitative analysis of texts (Gavora, 2000). Švařičck and Šed'ová (2007) describe the particular steps of this method, when historical events in each country are lined up and consequently compared (Fig. 1).

As Germany is considered to have laid the foundations of school physical education we shall start with the historical analysis of PE in this country.

\section{THE DEVELOPMENT OF PHYSICAL EDUCATION IN GERMANY}

Johann Basedow (1723-1790) was the first person to have conducted gymnastics as a part of education in Germany. He was the first modern writer and teacher of organized gymnastics. He is credited with founding the Dessau Philanthropinum $^{3}$ and writing about the Education of mind and body (Cazers \& Miller, 2000).

Guts Muths (1759-1839), one of the originators of gymnastics, wrote various books including gymnastics exercises for girls. For example, he wrote Gymnastics for youth, the first book on modern gymnastics, in which he describes the use of sloping beams, climbing poles, ladders and ropes along with the balancing beam and the swinging beam.

Another important person in the history of German physical education who also influenced gymnastic leaders in the Czech Republic (Rychtecký \& Fialová, 1993) and the USA (Cazers \& Miller, 2000) was Friedrich Ludwig Jahn (1778-1852). He was a member of a nineteenth century political and gymnastics movement called the "Turner" movement. He founded the "Turnverein" (a gymnastics club) and established the first public "Turnplatz" (an outdoor area for gymnastics) in Germany in 1811. Physical education was supported

\footnotetext{
3 The Dessau Philanthropinum constituted a new kind of school. Not only were the contents of the Philanthropists' lessons wholly new, but also their methods of teaching. They believed learning ought to be a pleasure, and possibly even playful a principle that generated sharp criticism.
} 
Fig. 1

Development of the PE in the USA, Germany and the Czech lands

(The picture summarizes the most important events in the PE history of the three countries. Here are what are supposed to be, simplified and transparently shown, the periods and the most important changes in PE.)

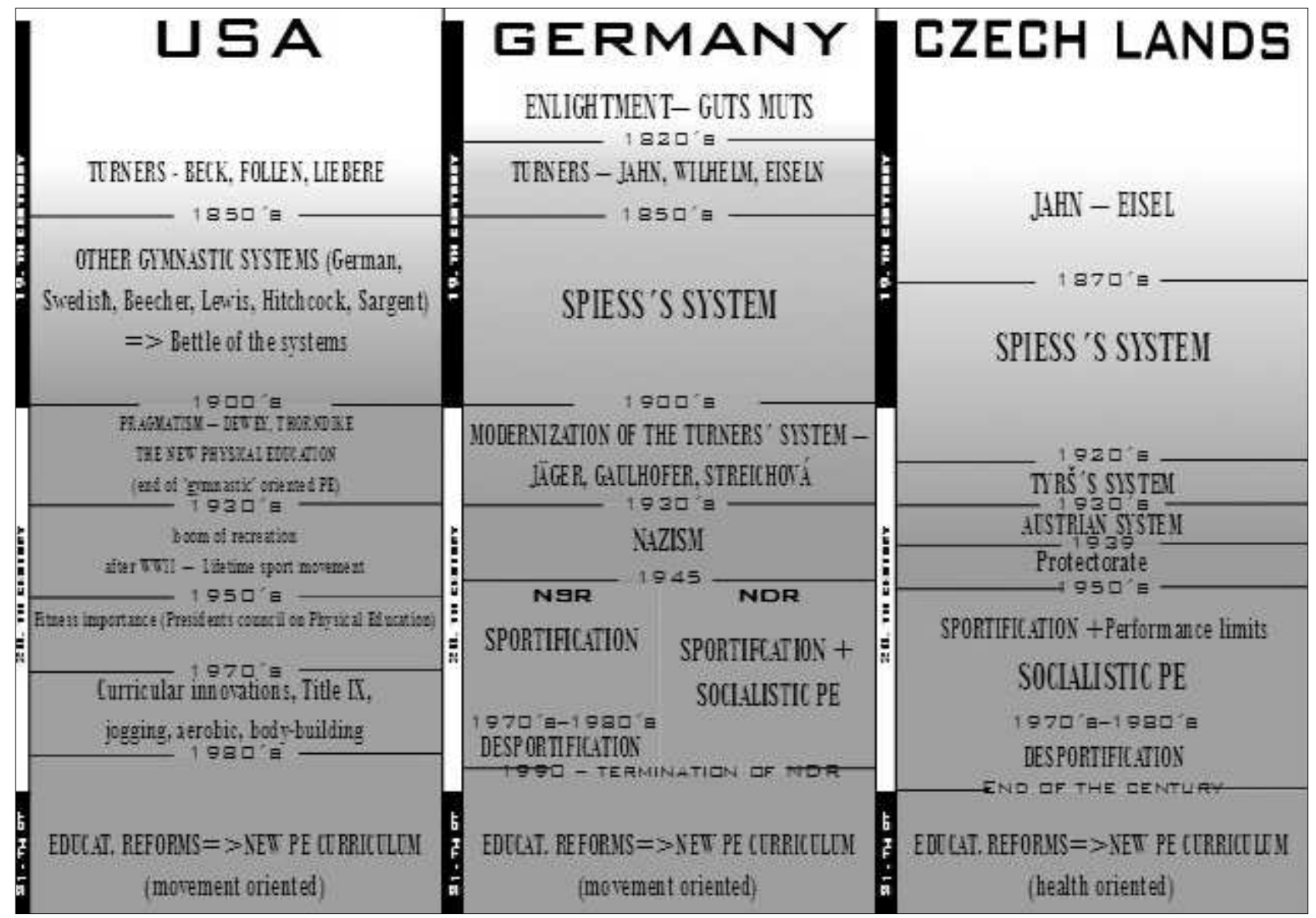

in Germany after France defeated the German army in 1806 , so the popularity of the Turnverein was useful in opposing the French domination of Germany in the $19^{\text {th }}$ century (Kössl, Krátký, \& Marek, 1986). After Napoleon's fall, it began to dissolve as the government thought the "Turners" (members of the Turnverein) were too liberal. In 1818 the "Turner" organization was outlawed and Jahn was arrested. But the members remained loyal. Some emigrated and laid foundations for physical education in many countries including the USA such as Fridrich Hecker, Charles Follen, Charles Beck, Francis Lieber. In Germany, in the 1860's, there was a revival of the organization, but it stayed out of politics (Brettschneider, Brandl-Bredenbeck, \& Rees, 1997).

Adolph Spiess (1810-1858) (the founder of school gymnastics) utilized the gymnastic ideas of Gutts Muths and Jahn in Switzerland. He formalized Jahn's system for use in schools and helped to add physical education to the German school curriculum.

For many years, the Germans presented a barrier to the inclusion of English sports and games in the formal gymnastic oriented PE curricula in Germany. Alternative gymnastic concepts from other countries were accepted at the governmental level earlier than the English sports and games concept. At the end of the $19^{\text {th }}$ century militarism started to emerge in German PE. The familiar ideas of Christian virtue was replaced with the ideology of the Aryan superman (Brettschneider, Brandl-Bredenbeck, \& Rees, 1997). Naul (2003, p. 43) points out an interesting fact: "It was only under Fascist rule in the 1930's that stronger support than ever before was given to the sports and games concept."

After World War II the process of sport promotion and shaping all elements of physical education with the spirit of sport had begun in the GDR (German Democratic Republic - East Germany) school system (Balz \& Neumann, 2005), whereas in West Germany there was a clear gap between the sport clubs and the school physical education system. The West German Sport Federation (DSB) and some state ministries of education campaigned to bridge this gap after 1966. Hence, the spirit of sport superseded all former physical 
education aims and objectives in Western and Eastern Germany (Hardman \& Naul, 2002). In both countries, the term sport even replaced the term physical education as the subject name (Kurz, 1993).

Since the late 1970's, the deconstruction of the sport concept started in West Germany. But the full deconstruction of the sport model emerged in the 1980 's, when the so called "student centred" teaching approaches were fostered and two alternative PE concepts appeared: Funke's (1983) "body education" concept, and the critical "Frankfurt group" (1982) concept. The so called "alternative concepts" to sports education became popular in Germany in the 1980's and early 1990 's, at primary schools in particular.

As a result of the educational reforms that were started after the German reunification in 1990 the sport oriented curriculum was being replaced by movement education. As Richter (2007) points out, NordrheinWestfalen is considered to be the leading state in the movement education approach (Ministerium für Schule, Wissenschaft und Forschung des Landes NordrheinWestfalen, 2001), but there still remains the sport oriented curriculum in some states of the German federation (Brettschneider, 2003).

\section{THE DEVELOPMENT OF PHYSICAL EDUCATION IN THE CZECH REPUBLIC}

In the 18th century physical education was not compulsory in terms of school education. However, Jakub Jan Ryba (1765-1815) paid attention to PE outside of the school system (Novotný, 2006).

In 1869 physical education became a compulsory subject with two lessons a week. The curriculum during those times was written by Adolph Spiess according to the Jahn-Eiselen system.

In February 1862 Miroslav Tyrš founded the Prague Gymnastics Association later renamed Prague Sokol. Eight other units were founded in Bohemia and Moravia in the same year. Many significant Czech patriots took part in this movement.

Paul Gautsche's announcement made in 1890 was important for the further development of PE (Kössl, Krátký, \& Marek, 1986). This announcement brought some changes to the PE curriculum (swimming, ice skating, etc. were included) and the building of new sports grounds was encouraged.

At the end of the $19^{\text {th }}$ century, the content of PE was influenced by some elements of the Swedish and French system and especially by the development of the international sport movement (Kössl \& Hubička, 1983). In 1911 the new curriculum was introduced. It included optional games, athletic exercises and other simple and consecutive exercises.
In 1925 the first congress of the Czech teachers and school supporters took place in Prague. As a consequence Tyrš's system became a basis of PE. PE teachers also gained an equal position with other teachers. After 1925, the health importance of PE was emphasized and for the first time it was called physical education. Winter sports and walks were also added to the list of curriculum and methodical materials were distributed to the teachers (Rychtecký \& Fialová, 1993).

The concept of PE radically changed after the release of a new curriculum in 1934. The influence of the French and New Austrian school was visible (Kössl, Krátký, \& Marek, 1986). More emphasis was put on athletic exercises, health education and competitiveness. In the period before World War II, physical education was under the Defence Act of Educating Citizens. This was dissolved with the protectorate of Bohemia and Moravia. War tasks became present in PE and the condition for physical education started to degenerate. The end of World War II left Czechoslovakian education (including $\mathrm{PE}$ ) in a worsened condition than before.

After the end of the war the school system was renewed. The events of February 1948 caused the codification of PE and the law of comprehensive schooling was passed. Physical education was influenced by a Russian physical culture concept in which physical fitness was supposed to ensure military strength, productivity, and nationalism (Nováček, Mužík, \& Kopřivová, 2001). Sports were viewed as a way of achieving international fame.

In 1955 the first worldwide Spartakiada took place and from that time on, the Spartakiada ${ }^{4}$ became a part of school physical education. Due to the Spartakiada rehearsals the tasks of school physical education were not fully carried out (Kössl, Krátký, \& Marek, 1986). During the 1970's sport activities became dominant in the PE curriculum and stress was put on performance and competitiveness. In the 1980's the so called "desportification" of Czech PE emerged. Stress was put especially on a positive attitude toward physical activity rather than sport.

The fall of Communism brought a kind of vacuum to school physical education. And, eventually the instruction of PE often had a recreational content. Since the mid 1990's, the situation has been improving due to the recent reforming process in the educational system and a more scientific curriculum. According to the newly introduced educational programmes (RVP ZV, 2007) a wide variety of $P E$ activities concerning health targets will be used in PE classes (Mužik, 1999).

\footnotetext{
4 Spartakiada (in Czech Spartakiáda) was a mass gymnastics display, which was held every five years at the Strahov Stadium in Prague, when Czechoslovakia was under Communist rule.
} 


\section{THE DEVELOPMENT OF PHYSICAL EDUCATION IN THE USA}

The beginnings of organized PE in the USA were connected with the German gymnasts (Turners), the activities of whom were first introduced by Charles Beck at the Round Hill School in 1826 (Lumpkin, 2004). His followers were Charles Follen and Francis Lieber (Siedentop, 2006; Vlček, 2009a). Gymnastics clubs were founded in a number of cities including New York, Pittsburg, Baltimore, Milwaukee, Louisville, and Chicago. After the end of the Civil War in 1865, the German Turners became very popular in the USA. In 1886 there were 231 clubs with twenty-four thousand members across the country (Kössl, Krátký, \& Marek, 1986).

Another approach to $\mathrm{PE}$ was introduced by $\mathrm{Ca}$ tharine Beecher. Her popular Physiology and Calisthenics for schools and families (1856) included chapters on the circulatory and other systems of the body and provided a description of schoolroom exercises for girls and boys (Stillwell \& Willgoose, 2006). Other systems, such as the Swedish one and that of Lewis, Delsartian, Hitchcock, and Sargent, had their patrons as well. These programmes became the prominent physical education system in the United States in what became known as the "Battle of the systems" (Siedentop, 2006). However, none of these systems prevailed. Instead, a unique American system emerged as traditional education was challenged by John Dewey and his colleagues (Cazers $\&$ Miller, 2000). Proponents of progressive education were emphasizing the importance of play and games in psychosocial as well as physical development (Singule, 1991).

Nineteenth century Protestant evangelism was another root of the belief that sports and games build character (Clifford, 2001). Here, the Young Men's Christian Association, or YMCA, played a critical role. The YMCA began in London in 1844. The Young Women's Christian Association or YWCA was founded in 1894. As originally conceptualized, the YMCA and YWCA encouraged Bible studies rather than exercise. However, when the organizations started opening chapters in the United States and Canada, its leaders found that Bible study classes did not attract as many young men and women as the gymnasiums of the Swiss and German gymnastic clubs. Consequently, many YMCA and YWCA buildings built after 1880 included weight rooms, gymnasiums, and swimming pools.

As a result of the popularity of the YMCA and YWCA, the philosophy of pragmatism and the modern Olympic movement, games, sports, and dance increasingly replaced formal gymnastic/calisthenic systems at the beginning of the $20^{\text {th }}$ century (Brettschneider, Brandl-Bredenbeck, \& Rees, 1997).
Surprisingly, many Americans were not physically fit for military service during World War I, and there were many post war efforts to implement physical education at all levels of schooling (Massengale, John, \& Swanson, 1997). During World War II, physical fitness was again required of soldiers, but it was also required of many others, particularly women, since the war effort required manual labour. Soldiers once again lacked in sufficient physical fitness to fulfil requirements (Kelly \& Melograno, 2004), so after the war, schools instituted more rigorous $\mathrm{PE}$ requirements, and there was a greater interest in teaching physical education. By the 1950's, there were over 400 colleges and universities in the USA offering majors in physical education and there was increasing recognition of the scientific foundation of PE.

But the fitness of the army in the Korean War fell short of expectations again (Kelly \& Melograno, 2004). Hence, the federal government set up the President's Council on physical fitness, which was supposed to raise fitness standards in schools across the country.

Yet, the series of recessions in the 1970's and the 1980 's brought about cutbacks in many school programmes, including physical education (Lumpkin, 2004). By the end of the 1970's, interest in the President's Council had waned and physical education courses began to emphasize lifetime sports (Zeigler, 2005). The American public spontaneously developed an intense interest in fitness in the late 1970's. School programmes were dominated by curricular innovations such as: movement education, adventure education, cooperative games, activities for girls and persons with disabilities.

One of the most significant shifts of the 1970's was the Title IX amendment to the Federal education act, which stipulated that all federally funded education programs could not discriminate on the basis of gender (Lumpkin, 2004). Enforcement of Title IX opened up many new opportunities for women in competitive athletics, both at the high school and collegiate levels.

In a continuation of the trends of the 1980's, during the 1990's many school districts have limited the amount of time students spend in physical education classes or have even dropped the program in response to economic problems or concerns about a poor quality of the curriculum.

Since 1983, American education has been in a period of educational reforms (Kelly \& Melograno, 2004; Hendl \& Vindušková, 2004; Jelínková, 1993). One promising step concerning the future of physical education was publication of the National Standards for Physical Education (NASPE, 2004). This document establishes content standards for the physical education school programme that clearly concentrates on "movement" education emphasizing the life long physical activity of the population (Dobrý \& Hendl, 2006; Kelly \& Melograno, 2004). 


\section{DISCUSSION}

In understanding the history of PE, we can notice some similar shifts in the concept of physical education caused by the mutual influence of the three countries. In the $19^{\text {th }}$ century PE in the USA and the Czech Republic (but also in other European countries), was influenced by the German gymnastic system. Later, both the German system, which emphasized gymnastics with large apparatus, and the Swedish system, which focused on light, progressive calisthenics, had numerous advocates in each country. Elements of Jahn's program and gymnastic equipment (the horizontal bar, parallel bars, balance beam etc.) can be seen in nearly every Czech, German and American physical education programme today.

The beginning of the $20^{\text {th }}$ century was characterised by the militarization of European physical education, whereas, in the USA, the English games and sport movement was being introduced during the 1890's. Pragmaticism, together with the rise of the modern Olympics (Guttmann, 1992; Kössl \& Hubička, 1983) and the popularity of the YMCA and YWCA, brought sports and games into the PE curriculum in the USA. The "Sportification" process of physical education significantly influenced the PE curriculum in European countries too, but it did not become evident until the end of World War II (Kössl, Krátký, \& Marek, 1986; Naul, 2003).

"The post war era was significant in sport for people with disabilities in America as well as in Europe" (Kudláček, 2006, p. 23). Especially in the USA, World War II had a tremendous impact on the development of adapted physical education (Seaman \& DePauw, 1982). Many war veterans claimed that their disabilities could not be corrected which led to the separation of corrective physical therapy and adapted physical education in 1952 (Sherrill, 1993).

The second half of the $20^{\text {th }}$ century brought a different development in the PE concept of these three countries. Life time sport activities along with other philosophies (human movement, humanistics, play education, sport education, experiential and adventure education, the fitness renaissance and the wellness movement) played a role in American PE development. In Western Germany the importance of sport in PE curricula grew in the 1960's and 1970's but decreased in the 1980's. The Soviet federation influenced PE in the former Czechoslovakia and other East European countries. The PE curriculum focused on sport and performance limits in the 1970's and resembled the German development in the 1980's when the importance of sport decreased in PE curricula.

The USA brought further development into German $\mathrm{PE}$ in the second half of the $20^{\text {th }}$ century especially due to the American troops and their families who stayed in
Germany after World War II. For example, they brought sporting games such as basketball and volleyball to Europe (Bretschneider et al., 1997). And, after a period of an anti-American movement in the 1960's (Brettschneider, Brandl-Bredenbeck, \& Rees, 1997) American influence returned to Germany in the 1970's and also came to the Czech Republic, especially after the political changes in 1989. This brought a new and fun introduction to sports such as outdoor activities, jogging and aerobics, body building and other movement concepts.

All three countries have been dealing with the same problems in recent decades concerning physical education. Many scientific reports have pointed out that in spite of the extensive warnings from health organisations, a large number of children and adolescents do not engage in regular physical activity (CDC, 2003; Dollman, Norton, \& Norton, 2005; Frömel \& Bauman, 2006; Hrčka \& Drdácká, 1992; Naul \& Brettschneider, 2005; Wolf, Manson, \& Coldiz, 2003). The ongoing educational reforms in all three countries, which clearly support health and active life style (Feingold \& Fiorentino; 2005; Richter, 2007; Vlček, 2009c), can therefore be regarded as a promising reaction.

\section{CONCLUSION}

Practitioners and researchers in the profession of physical education need to know where it has been, how it got there, and where it should be going. As we read reports and articles about the perspectives of physical education in Europe and in the USA (Frömel, 2001; Hardman, 2003; Hardman \& Marshall, 2000; etc.), it is not difficult to notice that the future of the subject and the discipline is being challenged. A careful study and understanding of the history and the development of our subject is a prerequisite to a full understanding of the overall situation. Germany and the USA have been undergoing educational reforms for a longer time than the Czech Republic, so we can gain some valuable information from them, which might help to reform Czech physical education.

\section{REFERENCES}

Balz, E., \& Neumann, P. (2005). Physical education in Germany. In U. Pühse \& M. Gerber (Eds.), International Comparison of Physical Education: Concepts, problems, prospects (pp. 292-309). Oxford: Meyer \& Meyer.

Bennett, B. L. (1970). A historian looks at comparative physical education. Gymnasion, 7, 10-13.

Brettschneider, W. D., Brandl-Bredenbeck, H. P., \& Rees C. R. (1997). Sportkultur und jugendliches Selbstkonzept: Eine interkulturell vergleichende Studie 
über Deutschland und die USA [Juventa]. Retrieved from http://books.google.cz/books?id=FSbH_TPgm TIC\&pg=PA52\&lpg=PA52\&dq=etic,+emic,+universa lismus\&source $=$ web\&ots $=2 \mathrm{fCnX}$ _OiTW\&sig=HriI_ xK8JlgiwAsZW3qLmcIok8I\&hl=cs\&sa=X\&oi=bo ok_result\&resnum=7\&ct=result\#PPA5,M1

Brettschneider, W. D. (Ed.). (2003). Die SPRINT Studie: Eine Untersuchung zur Situation des Schulsports in Deutschland. Retrieved from http://bildungsklick.de/ datei-archiv/40033/gesamtbericht_dsb_sprint_studie.pdf

Cazers, G., \& Miller, G. (2000). The German contribution to American physical education: A historical perspective. JOPERD, 71(1), 44-48.

CDC. (2003). Prevalence of physical activity including lifestyle activities among adults: United States 2000-2001. Morbidity an Mortality Weekly Report, 52(32), 764-769.

Clifford, P. (2001). Muscular christianity: Manhood and sports in protestant America, 1880-1920. Mass: Harvard U Press.

Dobrý, L., \& Hendl, J. (2006). Národní standardy tělesné výchovy v USA. Těl. Vých. a Sport Mládeže, 72(6), 2-14.

Dollman, J., Norton, K., \& Norton, L. (2005). Evidence for secular trends in children's physical activity behaviour. British Journal of Sport Medicine, 39, 892-897.

Editorial. (2004). Editorial. International Journal of Physical Education, 4, 143.

Feingold, R., S., \& Fiorentino, L. (2005). United States of America. In U. Pühse \& M. Gerber (Eds.), International Comparison of Physical Education (pp. 699-713). New York: Mayer \& Mayer.

Frömel, K. (2001). Tělesná výchova a sport v systému vzdělávání a výchovy v počátku tisíciletí. Česká kinantropologie, 5(1), 39-48.

Frömel, K., \& Bauman, A. (2006). Intenzita a objem pohybové aktivity 15-69leté populace České republiky. Ceská kinantropologie, 10(1), 13-27.

Gavora, P. (2000). Úvod do pedagogického výzkumu. Brno: Paido.

Guttmann, A. (1992). The Olympics: A history of the modern games. Chicago: University of Illinois Press.

Haag, H. (1986). Research methodology in sport science: Implications for the comparative research approach - 1982. In J. C. Pooley \& C. A. Pooley (Eds.), Proceedings from the Second International Seminar on Comparative Physical Education and Sport (pp. 89-110).

Haag, H. (1989). Sportpädagogik. In H. Haag, B. Strauss, \& S. Heinze (Eds.), Theorie und Themenfelder der Sportwissenschaft: Orinetierungshilfen zur Konzipierung sport wissenschaftlicher Untersuchungen (pp. 48-69). Schorndorf: Hofman.
Hardman, K. (2000). Comparative physical education and sport. ICSSPE Directory of Sport Science, 28, 59-77.

Hardman, K. (2003). Worldwide survey on the state and status of physical education in schools: Foundations for deconstruction and reconstruction of physical education. In K. Hardman (Ed.), Physical Education: Deconstruction and reconstruction - Issues and directions (pp. 15-34). Schorndorf: Hofmann.

Hardman, K., \& Marshall, J. (2000). The state and status of physical education in schools in international context. European Physical Education Review, 6(3), 203-229.

Hendl, J. (2008). Kvalitativní výzkum: základní metody a aplikace. Praha: Portál.

Hendl, J., \& Vindušková, J. (2004). Standardy pro tělesnou výchovu na amerických školách. Česká kinantropologie, 8(2), 33-48.

Hrčka, J., \& Drdácká, B. (1992). Rekreační tělesná výchova a sport. Bratislava: SPN.

Jelínková, V. (1993). Deset let marných snah o reformu amerického základního a středního školství. Praha: ÚIV.

Kelly, L., \& Melograno, V. (2004). Developing the physical education curriculum: An achievement based approach. Champaign, IL: Human Kinetics.

Kössl, J., \& Hubička, V. (1983). Vývoj mezinárodního olympijského hnutí a jeho současné problémy. Olympia: Praha.

Kössl, J., Krátký, F., \& Marek, J. (1986). Dějiny tělesné výchovy od roku 1948 do současnosti. Olympia: Praha.

Kössl, J., Štumbauer, J., \& Waic, M. (2004). Vybrané kapitoly z dějin tělesné kultury. Praha: Karolinum.

Kudláček, M. (2006). American adapted physical education in the first half of the 20th century. Acta Universitatis Palackianae Olomucensis. Gymnica, 36(1), 23-28.

Kudlorz, P. (1989). Comparative physical education: An international scientific approach. International Review of Education, 35(1), 65-72.

Kurz, D. (1993). Leibes erziehung und Schulsport in der Bundesrepublik Deutschland: Epochen einer Fachdidaktik. Bielefeld: Universität Bielefeld.

Lumpkin, A. (2004). Introduction to physical education, exercise science, and sport studies. McGraw-Hill Humanities/Social Sciences/Languages.

Massengale, J., \& Swanson, R. (Eds.). (1997). The history of exercise and sport science. Champaign, IL: Human Kinetics.

Ministerium für Schule, Wissenschaft und Forschung des Landes Nordrhein-Westfalen. (2001). Richtlinien und Lehrpläne für die Sekundarstufe I - Gymnasium in Nordrhein-Westfalen. Retrieved 20. 8. 2009 from the World Wide Web: http://www.ritterbach.de/ 1p_online/3426.pdf 
Muzik, V. (1999). Gesundheitlich vorbeugende Körpererziehung: Eine neue Richtung in der Tschechischen Schule. In J. C. Bussard \& F. Roth (Ed.), Which physical education for which school? (pp.91-96). Berne: SVSS.

Naul, R. (2003). Koncepce školní tělesné výchovy v Evrope. Česká kinantropologie, 7(1), 39-53.

Naul, R., \& Brettschneider, W. D. (2005). Young peoples' lifestyles and sendetariness in Europe. Acta Universitatis Carolinae, Kinantropologica, 41(2), 25-34.

Naul, R., \& Hardmann, K. (2002). Sport and physical education in Germany. Retrieved 19. 12. 2008 from the World Wide Web: http://books.google.cz/ books?id=uOL9-_5ajZ8C\&pg=PA16\&lpg=PA16\&dq =german+physical+education+history\&source=bl\&o ts=6vVlFsQP_o\&sig=jSeTAZgX3fcfhnXsyWRz5nx2 WMo\&hl=cs\&sa=X\&oi=book_result\&resnum $=8 \& c t$ $=$ result\#PPP1,M1

NASPE - National Association for Sport and Physical Education. (2004). Moving into the future: National standards for physical education (2nd ed.). Reston, VA: Author.

Nováček, V., Mužík, V., \& Kopřivová, J. (2001). Vybrané kapitoly z teorie a didaktiky tělesné výchovy. Brno: Pedagogická fakulta MU.

Novotný, F. (2006). Stručný přehled dějin tělesné výchovy. Univerzita J. E. Purkyně: Ústí nad Labem.

Pühse, U., \& Gerber, M. (Eds.). (2005). International comparation of physical education. New York: Mayer \& Mayer.

Richter, Ch. (2007). Concepts of physical education in Europe: Movement, sport and health. International Journal of Physical Education, 44, 101-105.

Rychtecký, A., \& Fialová, L. (1993). Didaktika školni tělesné výchovy. Praha: Karolinum.

Seaman, J. A., \& DePauw, K. D. (1982). The new adapted physical education. Palo Alto, CA: Mayfield Publishing Company.

Sherrill, C. (1993). Adapted physical activity, recreation and sport: Crossdisciplinary and lifespan. Dubuque, IA: Brown \& Benchmark.

Siedentop, D. (2006). Introduction to physical education, fitness, and sport. McGraw Hill.

Singule, F. (1991). Americká pragmatická pedagogika: John Dewey a jeho američtí následovníci. Praha: SPN.

Stillwell, J. L., \& Willgoose, C. E. (2006). The physical education curriculum. Long Grove, IL: Waveland Press.

Švaříček, R., \& Šed'ová, K., et al. (2007). Kvalitativní výzkum v pedagogických vědách. Praha: Portál.

Trávníček, M. (2006). Různost pojetí výuky tělesné výchovy na 1. stupni ZŠ. In School and health 21. (pp. 561-575). Brno: Paido.

Vlček, P. (2009a). Vývoj koncepce americké školní tělesné výchovy. In Sborník referátů II. doktorandské konference KRCR FIM UHK (pp. 15-22). GAUDEAMUS: Hradec Králové.

Vlček, P. (2009b). Komparativní kinantropologie. Česká kinantropologie, 13(1), 82-95.

Vlček, P. (2009c). Vliv školských reforem na tvorbu kurikula tělesné výchovy v České republice, Spolkové republice Německo a Spojených státech amerických. Disertační práce, Univerzita Palackého, Fakulta tělesné kultury, Olomouc.

Výzkumný ústav pedagogický v Praze. (2007). Rámcový vzdélávací program pro základní vzdělávání - RVP $Z V$. Retrieved 8. 7. 2009 from the World Wide Web: http://www.vuppraha.cz/soubory/RVPZV_2007-07. pdf

Wolf, A. M., Manson, J. E., \& Coldiz, G. A. (2003) The economic impact of owerweight, obesity, and weight loss. In R. H. Eckel (Ed.), Obesity: Mechanisms and clinical management (p. 6). Philadelphia, PA: Lippincott, Williams \& Williams.

Zeigler, E. (2005). History and status of American physical education and educational sport. Victoria, BC: Trafford.

\section{SROVNÁNÍ VÝVOJE TĚLESNÉ VÝCHOVY V ČESKÉ REPUBLICE, NĚMECKU A USA - HISTORICKÝ POHLED \\ (Souhrn anglického textu)}

VÝCHODISKA: Politické, strukturní a ekonomické reformy v České republice po roce 1989 prrivodily také rychlé a hluboké změny ve vzdělávání mající vliv i na tělesnou výchovu. V souvislosti se sjednocováním Evropy a globalizačními tendencemi podobné změny probíhají i v dalších zemích.

CÍLE: Komplexita situace, rychlé změny a různé pedagogické tradice ztěžují vypracování systémového pohledu na současné reformy tělesné výchovy. Cílem př́spěvku je proto popsat nejdůležitější události v historii tělesné výchovy v České republice, Německu a Spojených státech amerických a objasnit jejich vliv na změny kurikula tělesné výchovy ve vybraných zemích. Účelem historické analýzy je předložit základní informace o vývoji tělesné výchovy ve vybraných zemích a umožnit tak další srovnání současných reforem tělesné výchovy.

METODIKA: Zvolenou metodologií je historickosrovnávací analýza, která popisuje a porovnává historický vývoj tělesné výchovy ve vybraných zemích.

VÝSLEDKY: Výsledky odhalují odlišnosti v historii tělesné výchovy v České republice, Spolkové republice Německo a Spojených státech amerických, ale také interkulturní vliv zemí na vývoj koncepce tělesné výchovy. Především turnerství ovlivnilo počátky evropské a americké tělesné výchovy. Později se vedle německého systému významně prosadily i další gymnastické systémy. Na počátku 20. století došlo v souvislosti s prosazující 
se pragmatickou filosofií ke změně v koncepci americké tělesné výchovy. Gymnastické systémy byly nahrazeny sportovně rekreační koncepcí, která ovlivňuje přístupy k tělesné výchově i v současnosti, a to nejen v USA, ale i v Evropě. Ve 20. století se v USA opakovaně objevovala otázka, jak zvýšit neuspokojivou zdatnost populace, a to vždy v souvislosti s válečnými konflikty. Rozdíly v pojetí tělesné výchovy v druhé polovině 20 . století byly způsobeny vlivem různé politické ideologie. Po ukončení studené války se tělesná výchova zaměřila na tzv. „life long activities“. V poslední době dochází k významnému podporování zdravotních benefitů aktivního životního stylu, problematika zdraví se dostává do kurikula tělesné výchovy, ale znaky německé gymnastiky jsou také stále patrné.

ZÁVĚRY: Výsledky potvrzují odlišnosti v koncepcích školní tělesné výchovy ve sledovaných zemích (v terminologii, funkcích předmětu, cílech, úkolech atd.) v různých časových obdobích. Naše zjištění také ukazují na skutečnost, že edukační reformy v Německé spolkové republice a Spojených státech amerických byly započaty o 10, respektive 20 let dříve než v České republice. Velice vhodným zdrojem informací pro české školství by proto mohly být další komparace současných reforem tělesné výchovy.

Klíčová slova: historie, koncepce tělesné výchovy, Česká republika, Spolková republika Německo, USA.

\section{PhDr. Petr Vlček, Ph.D.}

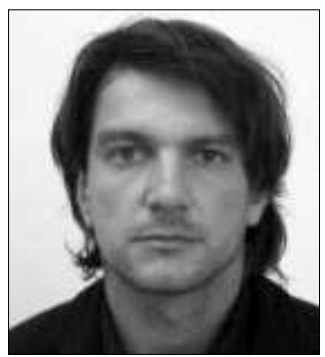

Masaryk University

Faculty of Education

Pořičí 538/31

60300 Brno

Czech Republic

\section{Education and previous work experience}

2010 - Palacký University, Olomouc - Ph.D.

2009 - Masaryk University, Brno - PhDr.

2000 - University in Hradec Králové - Mgr.

Educational stays:

2003 - King Street College, London

2000-2002 - Eichstaedt Universität, Germany

\section{First-line publications}

Vlček, P., \& Janík, T. (2010). Školské reformy a tvorba kurikula tělesné výchovy v České republice, Spolkové republice Nèmecko a Spojených státech amerických. Brno: Paido.

Mužík, V., \& Vlček, P. (2010). Škola, pohyb a zdraví výzkumné výsledky a projekty. Brno: MSD. 